\title{
Determinates of Youth Saving Habit in Kembeta Timbaro Zone: Case of Doyogena Woredad
}

\author{
Birhanu Hankamo Kintamo (MSc) \\ Department of Economics, Wolaita Sodo University, Ethiopia
}

\begin{abstract}
Most youths have low rate of saving behavior, so that improving saving behavior is a primary goal for people living in this part of the world. Improving saving behavior of individuals is given attention to look at a variety of savings services used by customer in the community. Improving this depends not only on attending of government provider but also on appropriate execution of recommending components of saving in household of the community and institutions or sectors. The objective of the study is to assess the saving habits of the youths (those in the age range of 18 to 30) and associated factors that determine the saving behavior of these youths in Doyogena Woreda. Both descriptive and econometrics methods used anddata from questionnaire were analyzed using SPSS and presented accordingly. The study found that there is a low saving behavior of the youths in Doyogena Woreda and they have a poor awareness of the financial services and packages. The factors determining the low saving behavior of the youths were the low financial literacy of the youths, the less parental socialization regarding saving the money, peer influence and less self-control practices of the respondents. The researcher recommended that it would be better if they get financial literacy form financial institutions and multimedia to alleviate their saving behavior. It would be much better if they control themselves towards managing the money they have and avoid bad temper. Good interaction between youths and their parents was recommended.
\end{abstract}

Keywords: Saving behavior, peer influence, financial literacy, and linear regression.

DOI: $10.7176 / \mathrm{JAAS} / 56-03$

Publication date:June $30^{\text {th }} 2019$

\section{Introduction}

\subsection{Background of the Study}

The motive of many countries' economic policy is maintaining stabilized and sustainable economic growth. The Ethiopian government has been undertaking different actions to ensure the country's economic growth. For instance, the first and second five years growth and transformation plans (GTP) are mentionable. The ultimate goals of these plans are to transform the agriculture sector leading economy in the country to industrialization in coming decades. The transformation, however, requires intensive capital accumulation and investment in infrastructures, educations, agriculture, science and technology, business and financial institutions. Thus, resources accumulated in the form of capital available for current and future investment are the foundation of economic development. Saving is one of the best mechanisms of accumulating capital.

According to Deaton (2005), serious problem confronting poor countries including Ethiopia is savings and investment gap. Because of this gap, these countries faced challenges to finance investments needed for growth from domestic saving. It is also common to see these countries to finance their investment in the short run partly throughdomestic government borrowings and/or foreign loan and grants but this can significantly increase debt burden and cannot be a solution in the long run (Rogg, 2006).In this context, a household saving is a crucial means of providing an insurance against the economic and social shocks. Likewise, savings at the household level are important for the welfare of family members in the course of economic development as a means to smooth income, to fund education and health for old age support when members become non-earners, and to leave as bequests to children. Additionally, a better practice of households saving behavior could develop the potential to finance investments (Girmaet al., 2013; Kifle, 2012; Abdelkhalek, et al., 2009).

Despite the important roles of saving in economic development process at a country level or household level in developing nations in general and in Ethiopia in particular, very few studies have been conducted on saving behavior of Youth. In line with this, the motive of this study was to investigate the factors that determine the saving behavior of youths' in Doyogena Woreda.

\subsection{Statement of the Problems}

Saving is a driving force of economic success and stability. Domestic household saving have become a major contributor to a country's economic success (Chengeet al., 2006). However, youth saving practice and culture in Ethiopia is very low and found at worst level (Anttansio (2001; Girmaet al., 2013). In addition, no adequate practice has been performed to educate the community about saving behavior. This was happened due to lack of adequate empirical result about the public savings practice and factors hindering the public to save.

The close relation between savings and growth makes the analysis of savings behavior naturally important for policy analysis. According to Agrawel et al (2009) saving behavior shows considerable variation across 
countries depending upon level of development and socio-economic structure and so one cannot be sure whether the results of a region or country under study may be applicable to a particular country or region of interest. Thus, cross-country regression analysis based on the assumption of homogeneity cannot be used as definitive study for any specific country of interest. For this reason, country and regional studies have an importance of their own (Agrawal et al, 2009).Most of the developing countries have low rate of saving behavior, so that improving saving behavior is a primary goal for people living in this part of the world (Mechael et al 2001).

Improving saving behavior of individuals is given attention to look at a variety of savings services used by customer in the community. Improving this depends not only on attending of government provider but also on appropriate execution of recommending components of saving in household of the community and institutions or sectors (Klauseetal, 1992).Investigation of factors associating with saving behavior assumes critical importance; Provision of saving services varies widely across individuals in Doyogena Woreda understanding these variations at the individual and in the community level in order to successfully implement any saving related policies and programs. As Gina et.al (2012) offers brief on a glimpse into saving patterns and performance of a large sample of in-school youth in Ghana. Findings from the baseline surveys in the Youth Save Ghana Experiment highlight the fact that these youth are active savers. However, they tend to save small amounts using informal methods over short periods of time, and for mostly consumptive purposes, such as school fees.

Thus, this study assessed the current status of youths' saving behavior both in household and in financial institutions and factors that influence utilization of these services, and to find out the possible reasons for underutilization of saving behavior using primary data \& secondary data source. The researcher thought that there is a relationship between age, gender, marital status, educational level family size, occupation, salary financial literacy, parental socialization, peer influence, self-control and saving behavior.

\subsection{Objective of the Study}

The general objective of this study is to assess the determinants of saving behavior of these youths in Doyogena Woreda. Specifically; to assess the youth saving behavior in Doyogena Woreda, to assess the awareness and use of bank services and essential packages and to assess factors affecting saving behavior and examine the relationship between the variables financial literacy, parental socialization, peer influence in Doyogena Woreda.

\section{Research Methodology}

\subsection{Research Design}

The research design of this study was descriptive survey method, which focuses on investigating the current status, practice, gaps or constraints of youth saving Habit of Doyogena Woreda.

\subsection{Participant of the Study}

The target population estimated in this study was youth in Doyogena Woreda.

\subsection{Linear Regression Model}

As econometric model linear regression model was applied in factors that determines the saving habits of the youth in study area to saw the effect of such variables. Accordingly, independent variable are defined and putted as determinants of saving habits of the youths' in the form of model as follows:

$\mathrm{SH}=\alpha+\beta 1$ prsp $+\beta 2 \mathrm{fl}+\beta 3$ prtsocio. $+\beta 4$ prsp. $+\beta 5$ selc 1

$\mathrm{Prsp}=$ Peers pressure, $\mathrm{fl}=$ Financial literacy, prtsocio $=$ Parental socialization, $\mathrm{slfco}=$ Self-control and

\subsection{Sampling Techniques}

A simple random sampling technique was usedinthisstudy to collect primary data. The sample size was determining formula (Dixon. C. and B. Leach, 1977) since target populationwas less than $10,000, \mathrm{Z}$ is $95 \%$ confidence limit that is $1.96, \mathrm{p}$ is 0.1 (proportion of the population to be included in the sample that is $10 \%$ ) $\mathrm{q}$ is 1 $\mathrm{p}=0.9, \mathrm{~N}$ is total number of population, e is margin or degree of accuracy desired (0.05), thus from total of 3430 youth's, 130 were randomly drawn.

$$
n=\frac{z^{2} p q}{0.05^{2}}=\frac{1.96^{2} 0.1 * 0.9}{0.05^{2}}=130 \text { youth. }
$$

\subsection{Tools of Data Collection}

Source of data to this study were both primary and secondary data. Primary data collected using a structured questionnaire with the help of trained enumerators. The questionnaire includes personal information, socio demographic profile of respondents, and outcome variables income of youths'.

\subsection{Data Analysis Methods}

Data generated from different sources were analyzed using SPSS. The objectives of data analysis include 
measuring central of tendency and variability, testing reliability and the hypotheses developed for the study. It is important to prevent error that may invalidate the conclusions.

\section{Data Analysis and Interpretation}

\subsection{Demographic Profile of youth}

The most frequently observed category of Gender was Female 80(62\%). The most frequently observed category of Marital Status was single 101(78\%). The observations for Age ranged from 18.00 to 30.00, with an average of $23.44(S D=3.41)$. Frequencies and percentages are presented in Table 1 .

Table 1: demographic profile of youth

\begin{tabular}{|c|c|c|c|c|}
\hline Variable & & $n$ & $\%$ & $N$ \\
\hline \multirow[t]{2}{*}{ Gender } & Female & 80 & 62 & \multirow{8}{*}{130} \\
\hline & Male & 50 & 38 & \\
\hline \multirow[t]{3}{*}{ Marital Status } & Married & 27 & 21 & \\
\hline & Single & 101 & 78 & \\
\hline & Widowed & 2 & 2 & \\
\hline \multirow[t]{3}{*}{ Age } & 20 and below & 26 & 20 & \\
\hline & 21 to 25 & 61 & 46.9 & \\
\hline & 26 to 30 & 43 & 33.1 & \\
\hline
\end{tabular}

Source: - survey of, 2018

The most frequently observed category of respondents live with alone 68(52\%). This means most of the surveyed youths were living alone and this may be difficult for saving. The most frequently observed category of Highest Level of Education was diploma 36(28\%) followed by degree holders which is $27 \%$. The most frequently observed category of Occupation was employed $68(52 \%)$. Meaning the most of the respondents of the questionnaire was employed. The most frequently observed category of having Additional Work was no 102(78\%). This clearly means most of the respondents didn't have additional. The observations for the number of the dependent ranged from 0.00 to 5.00 , with an average of $0.66(S D=0.98)$. Table 2 : the number of economic dependents

number of your family size under your economicalresponsibility (if there is)

\begin{tabular}{|l|l|l|} 
& Frequency & Percent \\
\hline .00 & 76 & 58.5 \\
\hline 1.00 & 34 & 26.2 \\
\hline 2.00 & 11 & 8.5 \\
\hline 3.00 & 7 & 5.4 \\
\hline 4.00 & 1 & .8 \\
\hline 5.00 & 1 & .8 \\
\hline Total & 130 & 100.0 \\
\hline
\end{tabular}

Source: - Survey, 2018

The observations for monthly Income from Salary ranged from 0.00 to 9000.00 , with an average of 2489.62 $(S D=1989.13)$. This does not mean they don't get money by simply looking at the smaller one. They may get it from other sources. The observations for monthly Income from Rent ranged from 0.00 to 0.00 , with an average of $0.00(S D=0.00)$. The observations for monthly Income from Remittance ranged from 0.00 to 1000.00 , with an average of $91.54(S D=204.71)$. The observations for monthly Income from Interest ranged from 0.00 to 500.00 , with an average of $3.91(S D=44.19)$. The observations for monthly Income from Other Sources ranged from 0.00 to 12500.00 , with an average of $339.23(S D=1241.25$.

Table 3: Monthly Income

\begin{tabular}{|l|r|r|r|r|r|}
\hline Variable & $M$ & $S D$ & $N$ & Min. & Max. \\
\hline monthly Income from Rent & 2489.62 & 1989.13 & 130 & 0.00 & 9000.00 \\
\cline { 2 - 6 } & 0.00 & 0.00 & 130 & 0.00 & 0.00 \\
\hline monthly Income from Remittance & 91.54 & 204.71 & 130 & 0.00 & 1000.00 \\
\cline { 2 - 6 } & 3.91 & 44.19 & 128 & 0.00 & 500.00 \\
\hline
\end{tabular}

Source: - Survey, 2018

\subsection{Saving Behavior of youth}

The most frequently observed category of habit of saving andRate of Saving Habit was70(54\%) and $42(32 \%)$ were bad and very bad respectively. Those who didn't have a saving habit were taken to be very bad at their saving habit. 
Table 4: Saving Behavior

\begin{tabular}{|l|l|c|c|}
\hline Variable & Response & $N$ & $\%$ \\
\hline Have Habit of & No & 70 & 54 \\
\cline { 2 - 4 } Saving & Yes & 60 & 46 \\
\hline \multirow{3}{*}{$\begin{array}{l}\text { The Saving Habit of the } \\
\text { respondents is }\end{array}$} & Excellent & 4 & 3.1 \\
\cline { 2 - 4 } & Very good & 9 & 6.9 \\
\cline { 2 - 4 } & Good & 42 & 32.3 \\
\cline { 2 - 4 } & Bad & 42 & 32.3 \\
\cline { 2 - 4 } & Very bad & 33 & 25.4 \\
\hline
\end{tabular}

Source: - Survey, 2018

According to most often the interviewees they don't have a good habit of saving. Their rate of saving was so poor. The proportion they save using different saving institutions and traditional methods of saving was very low. But they explained that they had a potential to save but they didn't save. There is a large gap between what they save and what they can save.The observations for Percent of youth Money they Saved ranged from 0.00 to 50.00, with an average of $14.52(\mathrm{SD}=16.31)$.

Table 5: Percent of their Income that they save,

how much Proportionyou save(birr)

\begin{tabular}{|l|l|l|}
\cline { 2 - 3 } \multicolumn{1}{c|}{} & Frequency & Percent \\
\hline below 10 & 10 & 7.7 \\
\hline $11-20$ & 10 & 7.7 \\
\hline above 20 & 47 & 36.2 \\
\hline None & 63 & 48.5 \\
\hline Total & 67 & 51.5 \\
\hline
\end{tabular}

Source: - Survey, 2018

The most frequently observed category of Places that the youths preferred to Save Money was bank $81(62 \%)$. The most frequently observed category of How often do the youth save money was monthly $52(40 \%)$ followed by quarterly which accounts for $7 \%$.

Table 6: Preferences and places of saving

\begin{tabular}{|l|l|c|c|}
\hline Variable & & $N$ & $\%$ \\
\hline \multirow{3}{*}{$\begin{array}{l}\text { Places the youths } \\
\text { prefer to Save Money }\end{array}$} & Bank & 81 & 62 \\
\cline { 2 - 4 } & credit union & 10 & 8 \\
\cline { 2 - 4 } & No preference & 39 & 30 \\
\hline \multirow{2}{*}{$\begin{array}{l}\text { places the youths save } \\
\text { Money }\end{array}$} & Bank & 57 & 44 \\
\cline { 2 - 4 } & credit union & 10 & 8 \\
\cline { 2 - 4 } & don't save & 63 & 48 \\
\hline \multirow{3}{*}{\begin{tabular}{l} 
Howe moften do youths \\
\cline { 2 - 4 }
\end{tabular}} & Monthly & 52 & 7 \\
\cline { 2 - 4 } & quarterly a year & 6 & 48 \\
\cline { 2 - 4 } & when I get money & 63 & 5 \\
\cline { 2 - 4 } & I don't save & & \\
\hline
\end{tabular}

Source: - Survey, 2018

The most frequently observed category of the variable in agreement level saying in order to save, they often compare prices before they make a purchase was agree $58(45 \%)$. Often consider whether the real necessity before making a purchase was agreeing66(51\%). Respondents who always follow a careful monthly budget were agreeing and disagree, each with an observed frequency of $50(38 \%)$. The most frequently observed category always have money available in the event of emergency was disagree $72(55 \%)$. The most frequently observed category of In order to save, respondentsplan to reduce my expenditure was agree 54(42\%). The most frequently observed category of save to achieve certain goals was agree $48(37 \%)$. Frequencies and percentages are presented in Table 8 below.Most of the interviewees used banks for saving, but they also save in IQUB to save their money. 
Table 7: saving behavior

\begin{tabular}{|l|l|l|l|l|l|}
\hline & & $\mathrm{n}$ & $\%$ & valid \% & Com \% \\
\hline \multirow{4}{*}{$\begin{array}{l}\text { In order to save, I often } \\
\text { compare prices before I } \\
\text { make a purchase }\end{array}$} & strongly disagree & 20 & 15.4 & 15.5 & 15.5 \\
\cline { 2 - 6 } & Disagree & 37 & 28.5 & 28.7 & 44.2 \\
\cline { 2 - 6 } & Undecided & 5 & 3.8 & 3.9 & 48.1 \\
\cline { 2 - 6 } & Agree & 58 & 44.6 & 45 & 93 \\
\cline { 2 - 6 } & strongly agree & 8 & 6.2 & 6.2 & 100 \\
\hline \multirow{3}{*}{$\begin{array}{l}\text { In order to save, I } \\
\text { always follow a careful }\end{array}$} & strongly disagree & 21 & 16.2 & 16.2 & 16.2 \\
\cline { 2 - 6 } & Disagree & 50 & 38.5 & 38.5 & 54.6 \\
\cline { 2 - 6 } & Undecided & 2 & 1.5 & 1.5 & 56.2 \\
\cline { 2 - 6 } & Agree & 50 & 38.5 & 38.5 & 94.6 \\
\cline { 2 - 6 } & strongly agree & 7 & 5.4 & 5.4 & 100 \\
\hline
\end{tabular}

Source: - Survey, 2018

\subsection{Awareness and Use of Bank Services and Essential Packages}

The most frequently observed category of knowing bank services and packages was yes $73(56 \%)$. This means the respondents were asked whether they know the bank services and packages most of them (56\%) did know the services and the packages. However very significant number of youths 54(42\%) didn't know the services and the packages provided by the banks or saving institutions.

Figure 3 Knowledge of bank services

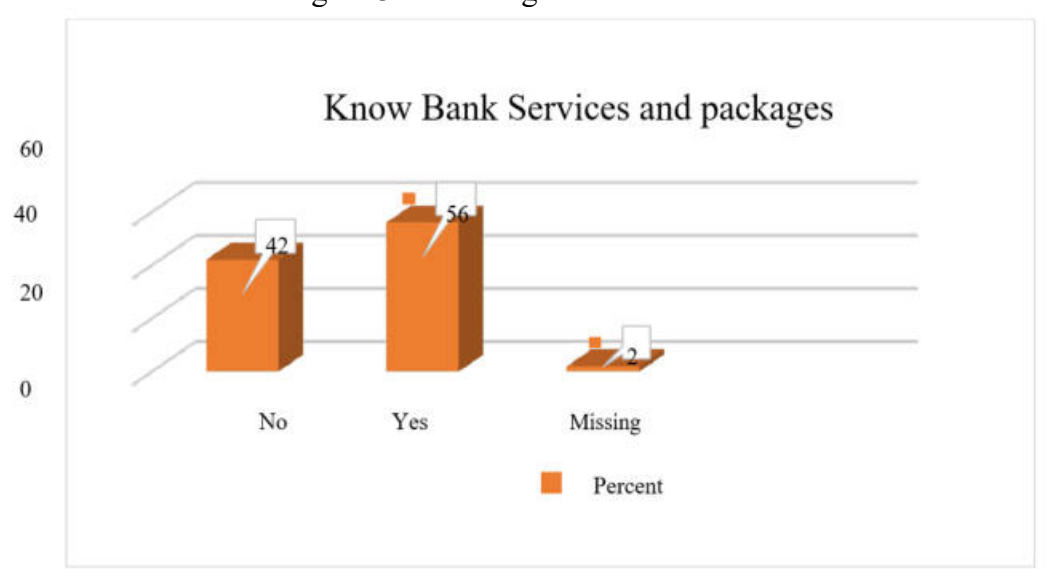

Source: Survey, 2018

Regarding their knowledge about the advantages and the risks of bank services most of them showed that they don't know it. The most frequently observed category of knowledge of the risks and advantages of the bank services and packages was no 70(54\%).

\subsection{Factors Affecting Saving Behavior}

Here the factors affecting the saving behavior of the youths are presented. The three scale agreement level was found by adding the frequency and percentages of the STRONGLY AGREE and the AGREE to call it on to the AGREE SIDE and the STRONGLY DISAGREE and the DISAGREE added up to be on the DISAGREE SIDE.

\subsubsection{Financial Literacy}

The table shown below details about the agreement level of the respondents the most frequently observed better understanding on how to invest money was agree 60(46\%). And hence according to most of the respondents $(55 \%)$ have better understanding of how to invest their money. But significant number of them 59(45\%) don't.

The most frequently observed category of the youths have a very clear idea of their financial needs during retirement was disagree 58(45\%). Most of the respondents $70(54 \%)$ disagree on the idea that have a very clear idea of their financial needs during retirement. The most frequently observed category of the youths have the habit of financial records for my income and expenditure was disagree 65(50\%). And hence most of the respondents $77(55 \%)$ disagreed on the idea that have the habit of financial records for their income and expenditure .The most frequently observed category of the youths have little or no difficulty in managing my money was agree $51(39 \%)$. Most of the respondents (48\%) disagree on the idea that they have little or no difficulty in managing my money. The most frequently observed category of the youths have the ability to prepare my own weekly (monthly) budget was disagree $57(44 \%)$. And most of the respondents disagree on the idea that they have the ability to prepare my own weekly (monthly) budget and this was on the disagree side 69(53\%). 
Table 8: Financial Literacy

\begin{tabular}{|c|c|c|c|c|c|c|c|c|c|}
\hline \multirow[t]{2}{*}{ Variable } & & \multicolumn{4}{|c|}{ Five Scale } & \multicolumn{4}{|c|}{ Three Scale } \\
\hline & & SD & $\mathrm{D}$ & $\mathrm{U}$ & A & SA & $\mathrm{D}$ & $\mathrm{U}$ & A \\
\hline \multirow{2}{*}{$\begin{array}{l}\text { I have better understanding of how to invest } \\
\text { mymoney }\end{array}$} & $N$ & 12 & 47 & 0 & 60 & 11 & 59 & 0 & 71 \\
\hline & $\%$ & 9 & 36 & 0 & 46 & 9 & 45 & 0 & 55 \\
\hline \multirow[t]{2}{*}{ Ihavea very clear idea of my } & $N$ & 12 & 58 & 6 & 47 & 7 & 70 & 6 & 54 \\
\hline & $\%$ & 9 & 45 & 5 & 36 & 5 & 54 & 5 & 42 \\
\hline \multirow{2}{*}{$\begin{array}{l}\text { I have the habit of financial records for } \\
\text { my income and expenditure }\end{array}$} & $N$ & 12 & 65 & 0 & 46 & 7 & 77 & 0 & 53 \\
\hline & $\%$ & 9 & 50 & 0 & 35 & 5 & 59 & 0 & 41 \\
\hline \multirow{2}{*}{$\begin{array}{l}\text { I havelittle or no difficulty inmanaging } \\
\text { my money }\end{array}$} & $N$ & 12 & 49 & 8 & 51 & 10 & 62 & 8 & 61 \\
\hline & $\%$ & 9 & 39 & 5 & 39 & 8 & 48 & 5 & 47 \\
\hline \multirow[t]{2}{*}{ I have the ability to prepare my own } & $N$ & 12 & 57 & 4 & 47 & 10 & 69 & 4 & 57 \\
\hline & $\%$ & 9 & 44 & 3 & 36 & 8 & 53 & 3 & 44 \\
\hline
\end{tabular}

Source: - Survey, 2018

3.4.2. Peer Influence

The most frequently observed category of As far as I know, some of my friends regularly do save with a saving account was agree 60(46\%). And hence according to most of the respondents $67(52 \%)$, the friends of the respondents regularly do save with a saving account. The most frequently observed category of I always discuss about money management issue (saving) with my friends was disagree 63(48\%). And hence according to most of the respondents $75(58 \%$ ), they disagree that they always discuss about money management issue (saving) with their friends. he most frequently observed category of I always compare the amount of saving and spending with my friends was disagree $66(51 \%)$. And hence according to most of the respondents $68(52 \%)$, they disagree with the idea that they always compare the amount of saving and spending with their friends. The most frequently observed category of respondent always involved in money spending activities with friends was agree $69(53 \%)$. And hence according to most of the respondents $78(60 \%)$, they agree with the idea that they always involve in money spending activities with friends.

Table 9: Peer Influence

\begin{tabular}{|c|c|c|c|c|c|c|c|c|c|}
\hline \multirow[t]{2}{*}{ Variable } & \multirow[t]{2}{*}{ Obs. } & \multicolumn{5}{|c|}{ Five Scale } & \multicolumn{3}{|c|}{ Three Scale } \\
\hline & & SD & $\mathrm{D}$ & $\mathrm{U}$ & $\mathrm{A}$ & SA & $\mathrm{D}$ & $\mathrm{U}$ & $\mathrm{A}$ \\
\hline \multirow[t]{2}{*}{ As far as I know, some of my friends } & $N$ & 12 & 47 & 4 & 60 & 7 & 59 & 4 & 67 \\
\hline & $\%$ & 9 & 36 & 3 & 46 & 5 & 45 & 3 & 52 \\
\hline \multirow{2}{*}{$\begin{array}{l}\text { I always discuss about money with } \\
\text { friends }\end{array}$} & $N$ & 12 & 63 & 2 & 46 & 7 & 75 & 2 & 53 \\
\hline & $\%$ & 9 & 49 & 2 & 35 & 5 & 58 & 2 & 41 \\
\hline \multirow{2}{*}{$\begin{array}{l}\text { I always compare the amount of } \\
\text { saving }\end{array}$} & $N$ & 2 & 66 & 4 & 46 & 12 & 68 & 4 & 58 \\
\hline & $\%$ & 2 & 51 & 3 & 35 & 9 & 52 & 3 & 45 \\
\hline \multirow{2}{*}{$\begin{array}{l}\text { I always involve in money } \\
\text { spendingactivities with friends }\end{array}$} & $N$ & 2 & 45 & 5 & 69 & 9 & 47 & 5 & 78 \\
\hline & $\%$ & 2 & 35 & 4 & 53 & 7 & 36 & 4 & 60 \\
\hline
\end{tabular}

Source: - Source: Our survey, 2018

\subsection{Relationship between Factors and Saving Behavior}

There was a significant positive correlation between financial literacy and saving habit $(r \mathrm{~s}=0.738, p<0.01)$. The correlation coefficient between financial literacy and saving habit was 0.738 indicating a large effect size. This indicates that as the financial literacy of the respondents increased, saving habit tends to increase.The regression analysis also showed the same result which is shown in the following table. The correlation coefficient 0.738 indicates that the there is a high correlation between the two variables. 
Table 10: Correlation Matrix

\begin{tabular}{|c|c|c|c|c|c|c|}
\hline & & $\begin{array}{l}\text { Havea } \\
\text { habitofSaving }\end{array}$ & $\begin{array}{l}\text { Financial } \\
\text { Literacy }\end{array}$ & $\begin{array}{l}\text { Parental } \\
\text { Socialization }\end{array}$ & $\begin{array}{l}\text { Peer } \\
\text { Influence }\end{array}$ & $\begin{array}{l}\text { Self- } \\
\text { control }\end{array}$ \\
\hline \multirow{2}{*}{$\begin{array}{l}\text { Have a habit } \\
\text { of Saving }\end{array}$} & Pearson Correlation & 1 & $.738 * *$ & $.590 * *$ & $-.547 * *$ & $.834 * *$ \\
\hline & Sig. (2-tailed) & & 0.000 & 0.000 & 0.000 & 0.000 \\
\hline \multirow{2}{*}{$\begin{array}{l}\text { Financial } \\
\text { Literacy }\end{array}$} & Pearson Correlation & $.738 * *$ & 1 & $.866^{* *}$ & $.514 * *$ & $-.888 * *$ \\
\hline & Sig. (2-tailed) & 0.000 & & 0.000 & 0.000 & 0.000 \\
\hline \multirow{2}{*}{$\begin{array}{l}\text { Parental } \\
\text { Socialization }\end{array}$} & Pearson Correlation & $.590 * *$ & $.866^{* *}$ & 1 & $.267 * *$ & $-.773 * *$ \\
\hline & Sig. (2-tailed) & 0.000 & 0.000 & & 0.002 & 0.000 \\
\hline \multirow{2}{*}{$\begin{array}{l}\text { Peer } \\
\text { Influence }\end{array}$} & Pearson Correlation & $-.547 * *$ & $.514 * *$ & $.267 * *$ & 1 & $-.435 * *$ \\
\hline & Sig. (2-tailed) & 0.000 & 0.000 & 0.002 & & 0.000 \\
\hline \multirow[t]{2}{*}{ Self-control } & Pearson Correlation & $.834 * *$ & $-.888 * *$ & $-.773 * *$ & $-.435 * *$ & 1 \\
\hline & Sig. (2-tailed) & 0.000 & 0.000 & 0.000 & 0.000 & \\
\hline
\end{tabular}

Source: Our survey, 2018

There was a significant positive correlation between Parental Socialization and saving habit $(r \mathrm{~s}=0.59$, $p<0.01)$. The correlation coefficient between Parental Socialization and saving habit the respondents save was 0.59 indicating a large effect size. This indicates that as the Parental Socialization of the respondents increased, saving habit tends to increase. The linear Analysis result also showed that there is strong evidence that the two variables are correlated.

Table 11: Linear regression between determinants and saving habit

Model Summary - $\quad$ -

\begin{tabular}{|l|l|l|l|l|}
\hline Model & $\mathrm{R}$ & $\mathrm{R}$ Square & AdjustedSquareR & Std. Error ofthe Estimate \\
\hline \multirow{4}{*}{1} & $.738^{\mathrm{a}}$ & .545 & .542 & .03879 \\
\cline { 2 - 5 } & $.590^{\mathrm{a}}$ & .348 & .343 & .40555 \\
\cline { 2 - 5 } & $.547^{\mathrm{a}}$ & .299 & .293 & .42070 \\
\cline { 2 - 5 } & $.834^{\mathrm{a}}$ & .695 & .693 & .27728 \\
\hline
\end{tabular}

a. Predictors: (Constant), financial literacy, Parental Socialization, peer pressure and self-controlSource our survey, 2018

There was a significant negative correlation between peer influence and saving habit $(r \mathrm{~s}=-0.547, p<0.01)$. The correlation coefficient between peer influence and saving habit of the respondents save was -0.547 indicating a large effect size. This indicates that as the peer influence of the respondent's increases, saving habit tends to decrease. The linear Analysis result also showed that there is strong evidence that the two variables are negatively correlated and it is shown in the table below. There was a significant negative correlation between self-control and saving habit $(r \mathrm{~s}=0.834, p<0.01)$. The correlation coefficient between monthly self-control and saving habit was 0.834 indicating a large effect size. This indicates that as the self-control of the respondents increases, saving habit tends to decrease. The linear Analysis result also showed that there is very strong evidence that the two variables are positively correlated and it is shown in the table below.

\section{Conclusion and Recommendation}

\subsection{Conclusion}

There was a less rate of saving habit in the study area. Most of the youths prefer banks and financial institutions to save their money. In order to save the respondents, most often compare prices before they make a purchase, often consider whether the real necessity before make a purchase and careful monthly budget were agree and disagree and the respondents don't have money available in the event of emergency and they a little bit plan to reduce my expenditure some of them save to achieve certain goals.Most of the youths in woreda, they don't have a very clear idea of their financial needs during retirement, the habit of financial records for their income and expenditure, have little or no difficulty in managing my money, and have the ability to prepare own weekly (monthly) budget. And hence they have very small financial literacy.Most of them don't save because their parents don't want them to save when they were little.

It is good that the friends of the respondents regularly do save with a saving account. But the friends, they don't always discuss about money management issue (saving) with their friends, and they don't compare the amount of saving and spending with their friends but instead they friends involved in money spending activities with friends. There was a significant positive correlation between saving habit and each of the variables gender, who the respondents live with, occupation, having additional work, financial literacy, parental socialization and self-control. And there was a significant negative correlation between saving habit and each of the variables number of economic dependents, peer influence. There were no any significance between the other demographic profiles and saving habit. 


\subsection{Recommendations}

Based on our research findings, the following points are recommended

$\checkmark$ The community has to provide awareness how to saving habitexercising it starting today deciding to save for tomorrow;

$\checkmark$ Giving training and awareness on how to develop saving habit based on factor affecting the saving habit of youth in Doyogena Woreda and

$\checkmark$ Significant number of the youths don't have better understanding of how to invest their money and most of the youths don't have a very clear idea of their financial needs during retirement, the habit of financial records for their income and expenditure, have little or no that the municipality might consider as an option of waste management thereby income generating.

\section{References}

Agrawal et al, (2009). Saving in Australia:Howdo savers decide on the amount? EconomicPapers: A journal of applied economics and policy, 19: 33-43.'

Attanasio, O.P. (2001). Cohort analysis of savings behavior by US households. The Journal of Human Resources, 33(3), 575-609.

Birkeland Fredrik Berggren (2013) the saving motives of dutch households and the effect of individual characteristics on the importance of saving motives. Master's Thesis is carried out as a part of the education at the University of Agder. University of Agder.

Deaton AS (2005), Franco Modigliani and the life cycle theory consumption.BancanationaledelLavoro Quarterly Review.

Gina A.N. Chowa, Mat Despard, \& Isaac Osei-Akoto (2012); Youth Saving Patterns andPerformance in Ghana; Youth Save Research Brief No. 12-36

Klause, S. Steven B.Webb,and Giancarlo Corsetti, (1992). Household Saving in Developing Countries: First Cross-Country Evidence. The world bank economic review, VOL. 6, NO. 3; 529-547.

Ajzen, I. (1991). The theory of planned behaviour. Organizational Behaviour and Human Decision Processes, 50 , 179-211.

Atryeetey, e., \&Grockel, F.A. (1991).Mobilizing domestic resources for capital formation in Ghana: the role of informal financial sectors, AERC research paper 3.

Baumeister, Roy F.(2002). Yielding to Temptation: Self-Control Failure, Impulsive Purchasing, and Consumer Behavior," Journal of Consumer Research, 28 (March),670-76 